INTIQAD: JURNAL AGAMA DAN PENDIDIKAN ISLAM

ISSN 1979-9950 (print) || ISSN 2598-0033 (online), http://jurnal.umsu.ac.id/index.php/intiqad DOI: https://doi.org/10.30596/intiqad.v11i1.3138

Vol. 11, No. 1 (Juni 2019)

\title{
Kontribusi Pondok Pesantren Az-Zuhroh Besilam Dalam Menghadirkan Mubaligh Di Kabupaten Langkat
}

\author{
Muhizar Muchtar \\ Universitas Sumatera Utara, Sekolah Tinggi Agama Islam Jam'iyah Mahmudiyah, \\ Universitas Muslim Nusantara \\ email: $\underline{\text { muhizarm@yahoo.com }}$
}

\begin{abstract}
This research uses qualitative naturalistic approach in collecting data by using observation instruments, questionnaires and interviews to the samples. The location of the research was conducted at Az-Zuhroh Besilam boarding school addressed in Besilam Village, Padang Tualang District, Langkat Regency. Implementation of this research conducted in 2017 in November until December 2017. In this research, the characteristics of this research subject is the head of the boarding school, the board of teachers, and the students of boarding school Az-Zuhroh. The results of this study are as follows: 1) The guidance system in Pondok Pesantren Az-Zuhrah Besilam Babussalam related in the development of talents and interests of students made in the form of extracurricular activities such as da'wah cadres, 2) The role and contribution given by Pondok Pesantren Az-Zuhroh Besilam Babussalam in giving birth to reliable young mubaligh by supporting various programs so that students can develop their da'wah potential, 3) Islamic education institution developed through boarding school Az-Zuhrah Besilam Babussalam is the development of mission of da'wah and education to society especially need continuously continue to be developed internally while still increasing the supporting facilities, teaching staff, and pesantren activities more innovative in the learning process.
\end{abstract}

Keywords: Boarding School, Missionary, Mubaliq.
Artikel Info

Received:

22 Januari 2019

Revised:

17 Maret 2019

Accepted:

21 April 2019

Published:

17 Juni 2019 
Pelaksanaan penelitian ini dilaksanakan pada tahun $2017 \mathrm{di}$ bulan Nopember sampai dengan bulan Desember 2017. Dalam penelitian ini, karakteristik subjek penelitian ini adalah kepala pondok pesantren, para dewan guru, dan para santri pondok pesantren Az-Zuhroh. Adapun hasil penelitian ini adalah sebagai berikut, 1) Sistem pembinaan di Pondok Pesantren Az-Zuhrah Besilam Babussalam terkait dalam pengembangan bakat dan minat siswa dibuat dalam bentuk kegiatan ekstrakurikuler seperti kader dakwah., 2) Peran serta kontribusi yang diberikan oleh Pondok Pesantren AzZuhrah Besilam Babussalam dalam melahirkan para mubaligh muda yang handal dengan mendukung berbagai program yang ada sehingga santri dapat mengembang potensi berdakwahnya., 3) Lembaga pendidikan Islam yang dikembangkan melalui pondok pesantren Az-Zuhrah Besilam Babussalam merupakan pengembangan misi dakwah dan pendidikan kepada masyarakat khususnya perlu secara terus menerus dikembengkan secara internal dengan tetap meningkat sarana prasarana pendukung, tenaga pengajar, dan kegiatan pesantren yang lebih inovatif dalam proses pembalajaran.

Kata Kunci: Pondok Pesantren, Dakwah, Mubalig.

\section{A. Pendahuluan}

Pelaksanaan dakwah Islam dewasa ini semakin komplek sehingga membawa perubahan pada masyarakat baik cara berpikirnya, bersikap maupun bertingkah laku. Penyelenggaraan dakwah dapat dilaksanakan dalam bentuk formal dan nonformal. Salah satu penyelenggaraan dakwah dalam bentuk non formal yaitu melalui pengajian yang diadakan oleh perorangan, kelompokkelompok, dan sebagainya, yang biasanya diisi dengan ceramah-ceramah, diskusi-diskusi, kursus-kursus agama untuk memperdalam masalah-masalah atau bidang-bidang ajaran agama. Dengan dakwah maka Islam dapat menyebar ke seluruh pelosok penjuru dunia dan di kenal di berbagai kalangan baik tua maupun muda.

Pondok pesantren sebagai suatu sistem pendidikan yang tumbuh dan berkembang di dalam masyarakat dijadikan tumpuhan dan harapan untuk dijadikan suatu model pendidikan sebagai variasi lain dan bahkan dapat menjadi alternatif lain dalam pengembangan masyarakat guna 
Vol. 11, No. 1 (Juni 2019)

menjawab tantangan masalah urbanisasi dan pembangunan dewasa ini. Oleh karenanya pondok pesantren dengan fungsinya harus berada di tengah- tengah kehidupan manusia dalam setiap perkembangannya, dan dapat memberi dasar- dasar wawasan dalam masalah pengetahuan baik dasar aqidah maupun dasar syari'ah. Islam sebagai agama rahmatan lil alamin menganjurkan ummat manusia untuk memahami ajaran-ajaran Islam secara tepat agar dapat dijabarkan dalam kehidupan yang nyata sehari-hari.

Dalam perkembangannya lembaga pendidikan pesantren seperti terpinggirkan, tidak diberikan fasilitas sebagaimana mestinya bahkan dianggap sebagai lembaga kelas dua karena dianggap tidak sesuai dengan perkembangan zaman. Walaupun anggapan itu terbukti salah karena justru perkembagan pesantren menjadi tidak terbendung, bahkan ketika pemerintah tidak memberikan kesempatan dan bantuan yang layak, pesantren tetap menunjukan kiprah sumbang asihnya pada bangsa ini. Sekali lagi pesantren menunjukan kualitas semangat perjuangannya.
Pesantren merupakan pelopor sistem pendidikan Islam di Indonesia, didirikan karena adanya tuntutan dan kebutuhan zaman, hal ini dapat dilihat dari perjalanan sejarah dimana bila diruntut kembali, sesungguhnya pesantren dilahirkan atas kesadaran kewajiban dakwah Islamiyah yakni menyebarkan dan mengembangkan ajaran Islam sekaligus mencetak kaderkader ulama dan da'i. Dari pesantren inilah banyak melahirkan kader-kader pendakwa agama Islam yang menyebarkan ajaran agama Islam keseluruh pelosok nusantara. Dalam pondok pesantren ini santri di didik ilmu agama dan pengetahuan sehingga setelah mereka memondok maka mereka akan mengajarkan ilmu yang mereka dapat untuk menjadi mubaligh penyampaian ajaran agama Islam kepada masyarakat luas.

Ada beberapa kajian yang dibahas dalam penelitian ini, diantaranya adalah: 1) Bagaimanakah pendidikan Islam di pondok pesantren Az-Zuhroh Besilam?; 2) Bagaimanakah peran Pondok Pesantren Az-Zuhroh dalam melahirkan mubaligh di Kabupaten Langkat?; 3) Bagaimanakah pendidikan Islam di Pondok Pesantren Az-Zuhroh Besilam 
Vol. 11, No. 1 (Juni 2019)

dalam melahirkan mubaligh di Kabupaten Langkat?

\section{B. Tinjauan Pustaka}

\section{Pendidikan Islam Di Pondok Pesantren}

$\begin{array}{rrr}\text { Seiring } & \text { dengan } & \text { laju } \\ \text { perkembangan } & \text { masyarakat maka }\end{array}$
pendidikan pesantren baik tempat bentuk hingga substansi telah jauh mengalami perubahan. Pesantren tidak lagi sesederhana seperti apa yang digambarkan seseorang akan tetapi pesantren dapat mengalami perubahan sesuai dengan pertumbuhan dan perkembangan zaman. Ada juga yang mengartikan pesantren adalah suatu lembaga pendidikan Islam Indonesia yang bersifat "tradisional" untuk mendalami ilmu tentang agama Islam dan mengamalkan sebagai pedoman hidup keseharian. Dalam kamus besar bahasa Indonesia pesantren diartikan sebagai asrama tempat santri atau tempat murid-murid belajar mengaji.

Pondok pesantren sebagai suatu sistem pendidikan yang tumbuh dan berkembang di dalam masyarakat dijadikan tumpuhan dan harapan untuk dijadikan suatu model pendidikan sebagai variasi lain dan bahkan dapat menjadi alternatif lain dalam pengembangan masyarakat guna menjawab tantangan masalah urbanisasi dan pembangunan dewasa ini. Oleh karenanya pondok pesantren dengan fungsinya harus berada di tengah- tengah kehidupan manusia dalam setiap perkembangannya, dan dapat memberi dasar- dasar wawasan dalam masalah pengetahuan baik dasar aqidah maupun dasar syari'ah. Islam sebagai agama rahmatan lil alamin menganjurkan ummat manusia untuk memahami ajaran-ajaran Islam secara tepat agar dapat dijabarkan dalam kehidupan yang nyata. Sehingga tercipta masyarakat madani dalam tata kehidupan sosial yang baik.

Pondok pesantren di pandang sebagai lembaga pendidikan tradisional Islam indigenos karena tradisinya yang panjang di Indonesia. Peasantren pada masa modern dan kontemporer pada umumnya didirikan oleh kiai yang berafiliasi pada Nahdlatul Ulama (NU)." Pesantren merupakan sebuah pendidikan tradisional yang para siswanya tinggal bersama dan belajar di

\footnotetext{
${ }^{1}$ Sutrisno, Pembaharuan dan
} Pengembangan Pendidikan Islam. (Yogyakarta : Fadilatama, 2011), h. 56. 
bawah bimbingan guru yang lebih dikenal dengan sebutan kiai dan mempunyai asrama untuk tempat menginap santri. Santri tersebut berada dalam kompleks yang juga menyediakan masjid untuk beribadah, ruang untuk belajar, dan kegiatan keagamaan lainnya dalam mengembangkan potensi diri santri. Sehingga setelah tamat memondok di pesantren mereka dapat mempraktikkan ilmu-ilmu yang di dapat dalam pondok pesantren tersebut. Salah satu keahliannya yaitu sebagai juru dakwah atau mubaligh dalam meyampaikan ajaran agama di masyarakat.

$$
\text { Pondok pesantren }
$$

melaksanakan pendidikan keagamaan yang bersumber dari karya-karya Islam klasik. Pondok pesantren sebagai pusat pedalaman ilmu-ilmu agama Islam (tafaqquh fi al-din), pondok pesantren masih tetap diakui oleh masyarakat karena beranggapan bahwa pendidikan keperibadian pesantren lebih unggul dibandingkan pendidikan sekolah atau madrasah. Pesantren adalah lembaga pendidikan Islam yang didirikan untuk memahami, menghayati dan mengamalkan ajaran Islam dengan menekankan pentingnya moral Islam sebagai pedoman hidup bermasyarakat sehari-hari. Istilah pesantren telah akrab pemakaiannya di kalangan masyarakat untuk membedakan antara pendidikan Islam dan pendidikan umum.

Pesantren berasal dari kata santri dengan awalan pe dan akhiran an berarti tempat tinggal santri. Soegarda Poerbakawatja yang dikutip oleh Haidar Putra Daulay mengatakan pesantren berasal dari kata santri yaitu seseorang yang belajar agama Islam sehingga dengan demikian pesantren mempunyai arti tempat orang berkumpul untuk belajar agama Islam. ${ }^{2}$

Jadi, yang dimaksud dengan pondok pesantren adalah suatu lembaga pendidikan Islam dengan menetap dalam asrama (pondok) dengan seorang kyai, tuan guru sebagai tokoh utama dan masjid sebagai pusat lembaga dan menampung peserta didik (santri), yang belajar untuk memperdalami suatu ilmu agama Islam. Pondok pesantren juga mengajarkan materi tentang Islam, mencakup tata bahasa Arab, membaca Al-Qur'an, Tafsir, Etika, Sejarah dan ilmu kebatinan Islam. Pondok pesantren

\footnotetext{
${ }^{2}$ Haidarputra, Sejarah Pertumbuhan dan Pembaruan Pendidikan Islam di Indonesia. (Jakarta : Kencana, 2009), h. 61.
} 
Vol. 11, No. 1 (Juni 2019)

tidak membedakan tingkat sosial ekonomi orang tua peserta didik (santri), pendidikan orang tua peserta didik (santri), dengan menekankan pentingnya moral agama sebagai pedoman perilaku peserta didik (santri) sehari-hari, serta menekankan pentingnya moral keagamaan tersebut dalam menjalani kehidupan bermasyarakat.

$$
\text { Dalam perkembangannya, }
$$
pesantren tetap kokoh dan konsisten mengikatkan dirinya sebagai lembaga pendidikan yang mengajarkan dan mengembangkan nilai-nilai Islam. Realitas ini tidak saja dapat dilihat ketika pesantren menghadapi banyak tekanan dari pemerintah kolonial Belanda, namun pada masa pasca-proklamasi kemerdekaan pesantren justru dihadapkan pada suatu tantangan yang cukup berat yaitu adanya ekspansi sistem pendidikan umum dan madrasah modern. Di tengah kondisi yang demikian, di mana masyarakat semakin diperkenalkan dengan perubahanperubahan baru, eksistensi lembaga pendidikan pesantren tetap saja menjadi alternatif bagi pelestarian ajaran agama Islam. Pesantren justru tertantang untuk tetap survive dengan cara menempatkan dirinya sebagai lembaga yang mampu bersifat adaptatif menerima dinamika kehidupan.

"Islam adalah agama tauhid, maka iman kepada pencipta alam merupakan kenyataan yang bisa diterima oleh setiap akal sehat."3 Keberadaan ajaran agama Islam bukan saja membawa rahmat dan nikmat agi seluruh manusia, namun juga pada seluruh makhluk-makhluk lainnya. Prinsip ajaran Islam yang rahmatan lil 'alamin inilah yang menjadikan Islam tampil sebagai agama yang universal.

"Unversalitas ajaran agama Islam setidak-tidaknya dapat dilihat dari dua sudut, yaitu pada kelengkapan ajaran Islam itu sendiri dan pada karakter kandungan ajarannya." ${ }^{4}$ Islam mengajarkan seluruh aspek kehidupan manusia dari hal-hal yang besar hingga hal-hal yang kecil. Dari universal ajaran Islam ini maka Islam dapat diterima oleh semua kalangan baik atas mapun yang paling bawah. Islam tidak memandang harta ata kedudukan tetapi yang di

\footnotetext{
${ }^{3}$ Syekh Mohammad Bin Jameel
} Zeeno. Bimbingan Islam Untuk Pribadi dan Masyarakat. (Jakarta : Darul Haq, 2000), h. 13.

${ }^{4}$ Asrifin An Nakhrawie, Islam Itu Mudah Mengapa Dipersulit. Lamongan : Lumbung Insani, 2013), h. 12. 


\section{INTIQAD: JURNAL AGAMA DAN PENDIDIKAN ISLAM}

ISSN 1979-9950 (print) || ISSN 2598-0033 (online), http://jurnal.umsu.ac.id/index.php/intiqad DOI: https://doi.org/10.30596/intiqad.v11i1.3138

\section{Vol. 11, No. 1 (Juni 2019)}

pandang hanyalah tingkat taqwa seseorang kepada Allah SWT. Oleh karena itu, Islam merupakan agama yang paling sempurna apabila di bandingkan dengan agama yang lain, karena Islam menyempurnakan agama-agama sebelum Islam. Sebagaimana firman Allah SWT dalam surah al-Maidah ayat 3 sebagai berikut:

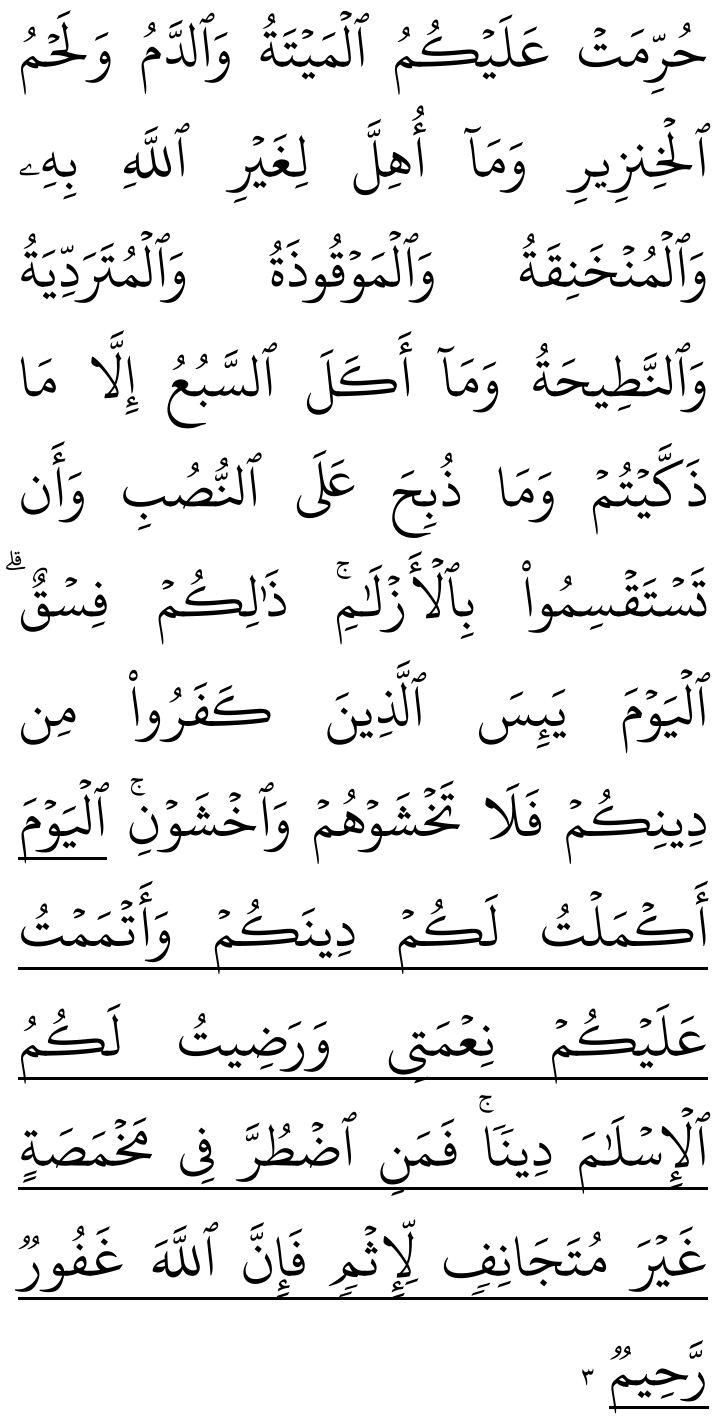

Artinya: " Diharamkan bagimu (memakan) bangkai, darah, daging babi, (daging hewan) yang disembelih atas nama selain Allah, yang tercekik, yang terpukul, yang jatuh, yang ditanduk, dan diterkam binatang buas, kecuali yang sempat kamu menyembelihnya, dan (diharamkan bagimu) yang disembelih untuk berhala. Dan (diharamkan juga) mengundi nasib dengan anak panah, (mengundi nasib dengan anak panah itu) adalah kefasikan. Pada hari ini orangorang kafir telah putus asa untuk (mengalahkan) agamamu, sebab itu janganlah kamu takut kepada mereka dan takutlah kepada-Ku. Pada hari Ini telah kusempurnakan untuk kamu agamamu, dan telah ku-cukupkan kepadamu nikmat-Ku, dan Telah $\mathrm{Ku}-$ ridhai Islam itu jadi agama bagimu. Maka barang siapa terpaksa karena kelaparan tanpa sengaja berbuat dosa, sesungguhnya Allah Maha Pengampun lagi Maha Penyayang. (QS. al-Maidah : 3)." 5

\section{Peran Pondok Pesantren Dalam Melahirkan Mubaligh}

Pesantren merupakan lembaga pendidikan Islam paling awal di Indonesia. Jenis lembaga pendidikan ini dapat dijumpai di berbagai wilayah Indonesia termasuk di Besilam. Tidak heran jika lembaga pendidikan ini memiliki beberapa sebutan lain. Melihat

\footnotetext{
${ }^{5}$ Departemen Agama RI, Al-Qur'an
} Tafsir Perkata Tajwid Kode Angka. Tangerang : Kalim, 2003), h. 67. 
Vol. 11, No. 1 (Juni 2019)

dari perkembangannya, Pondok Pesantren sangat menekankan pentingnya mempelajari ilmu ke-Islaman dari pada ilmu-ilmu umum. Karena pesantren bertujuan meninggikan moral, melatih dan mempertinggi semangat, menghargai nilai-nilai spiritual dan kemanusiaan, mengajarkan sikap dan tingkah laku yang jujur dan bermoral, dan menyiapkan para murid untuk hidup sederhana dan bersih hati. Dari keterangan tersebut dapat disimpulkan bahwa aspek perilaku dan spiritualitas mendapat tekanan penting sementara ilmu-ilmu pemgetahuan umum yang lebih bersifat duniawi tidak disebutkan sama sekali. Secara lebih luas, Pondok Pesantren memiliki peranan sebagai tempat reproduksi ulama, tempat penyebaran dan pembejalaran ilmu-ilmu ke-Islaman, dan penjaga serta pemelihara tradisi Islam.

Agama mempunyai kedudukan dan peranan yang sangat penting dan strategis, utamanya sebagai landasan spiritual, moral dan etika dalam hidup dan kehidupan umat manusia. Agama sebagai system nilai seharusnya dipahami, dihayati dan diamalkan oleh seluruh pemeluknya dalam tatanan kehidupan setiap individu, keluarga dan masyarakat serta menjiwai kehidupan berbangsa dan bernegara.

"Dari sudut doktrin, agama dapat didefenisikan sebagai sistem kebenarankebenaran umum yang memiliki kekuatan untuk membentuk karakter, asalkan kebenaran-kebenaran itu dianut secara tulus dan sungguh-sungguh dihayati."6 Sedangkan menurut Solatun dalam bukunya menyatakan agama merupakan suatu institusi yang sangat individual." ${ }^{\text {7 }}$ Dengan manusia beragama akan melahirkan manusia-manusia yang memiliki karakter dalam berperilaku berkehidupan. Agar memiliki sikap dan karakter yang baik maka perlunya penghayatan dan pendidikan agama bagi masyarakat itu sendiri. Agar masyarakat paham akan agama islam perlunya penyampaian ajaran Islam bagi masyarakat. Oleh sebab itu, perlu perannya seorang mubaigh dalam myampaiakan ajaran Islam tersebut.

Para muballig sebagai pelaksana kegiatan penyiaran agama mempunyai peranan yang sangat strategis. Karena

\footnotetext{
${ }^{6}$ Alfred North Whitehead. (2009). Mencari Tuhan Sepanjang Zaman. Penerjemah Alois Agus Nugroho. Bandung : Mizan. h. 4.

${ }^{7}$ Solatun. (2007). Islam dan Etika Komunikasi. Jakarta : Image. h. 3.
} 
berbicara masalah dakwah berarti berbicara masalah ummat dengan semua problematika. Sebab banyak kasus dan dari banyak fakta dakwah, kita melihat tanda-tanda betapa kemalahatan ummat (jamaah) tidak merupakan sesuatu yang obyektif atau dengan kata lain belum mampu diwujudkan oleh pelaksana dakwah. Hal ini merupakan salah satu problematika dari sisi pelaksana dakwah (muballigh), dimana sebagian aktivitas dakwah belum mampu menterjemahkan persoalan yang dihadapi umat secara rinci, untuk kemudian dicarikan jalan keluarnya dalam konteks dakwah Islam.

Seiring dengan perkembangan teknologi yang sangat pesat, diakui memang banyak menimbulkan dampak positif, akan tetapi juga perlu untuk diketahui disamping menimbulkan dampak positif juga menimbulkan dampak negatif yang lebih besar pengaruhnya dalam kehidupan manusia. Oleh karena itu, untuk mencapai kebutuhan manusia dengan seimbang antara kebutuhan jasmani dan rohani, maka pembangunan itu tidak hanya di tekankan pada bidang fisik tetapi juga ditekankan pada bidang nonfisik (spiritual).
Dakwah merupakan salah satu bentuk pembangunan spiritual. Karena Dakwah adalah suatu kegiatan ajakan baik dalam bentuk lisan, tulisan, tingkah laku dan sebagainya yang dilakukan secara sadar dan berencana dalam usaha mempengaruhi orang lain baik secara individual maupun secara kelompok supaya timbul dalam dirinya suatu pengertian, kesadaran, sikap penghayatan, serta pengamalan terhadap ajaran agama sebagai message yang disampaikan kepadanya dengan tanpa adanya unsur-unsur paksaan. ${ }^{8}$

Penyelenggaraan dakwah Islam dewasa ini semakin komplek sehingga membawa perubahan pada masyarakat baik cara berpikirnya, bersikap maupun bertingkah laku. Penyelenggaraan dakwah dapat dilaksanakan dalam bentuk formal dan nonformal. Salah satu penyelenggaraan dakwah dalam bentuk non formal yaitu melalui pengajian yang diadakan oleh perorangan, kelompokkelompok, dan sebagainya, yang biasanya diisi dengan ceramah-ceramah, diskusi-diskusi, kursus-kursus agama untuk memperdalam masalah-masalah atau bidang-bidang ajaran agama.

8 H. M. Arifin.2000. Psikologi Dakwah. Jakarta: PT Bumi Aksara. h. 6 
Vol. 11, No. 1 (Juni 2019)

Sistem pendidikan dipesantren tidak didasarkan pada kurikulum yang digunakan secara luas, tetapi diserahkan pada penyesuaian elastis antara kehendak kiai dengan kemampuan santrinya secara individual.

Ketika masih berlangsung dilanggar (surau) atau masjid, kurikulum pengajian masih dalam bentuk yang sederhana, yakni berupa inti ajaran islam yang mendasar. Rangkaian trio komponen ajaran islam yang berupa iman, islam dan insan atau dokrin, ritual, dan mistik telah menjadi perhatian kiai perintis pesantren sebagai kurikulum yang diajarkan kepada santrinya. Penyampaian tiga komponen ajaran Islam tersebut dalam bentuk yang paling mendasar, sebab disesuaikan dengan tingkat intelektual dengan masyarakat (santri) dan kualitas keberagamaannya pada waktu itu.

Peralihan dari langgar (surau) atau masjid lalu berkembang menjadi pondok pesantren ternyata membawa perubahan materi pengajaran. Dari sekedar pengetahuan menjadi suatu ilmu. Dalam perkembangan selanjutnya, santri perlu di berikan bukan hanya ilmu-ilmu yang terkait dengan ritual keseharian yang bersifat praktis-pragmatis, melainkan ilmu-ilmu yang berbau penalaran yang menggunakan referensi wahyu seperti ilmu kalam, bahkan ilmu-ilmu yang menggunakan cara pendekatan yang tepat kepada Allah seperti tasawuf. Ilmu kalam atau ilmu tauhid memberikan pemahaman dan keyakinan terhadap keesaan Allah, fikih memberikan cara-cara beribadah sebagai konsekuensi logis dari keimanan yang telah dimiliki seseorang pada penyempurnaan ibadah agar menjadi orang yang benar-benar dekat dengan Allah.

Dakwah merupakan salah satu kewajiban bagi setiap kaum muslimin untuk merubah sikap, perilaku dan ta ${ }^{e e}$ biat manusia agar sesuai dengan fitrahnya. Melaksanakan dakwah di tengah-tengah kehidupan masyarakat dengan kesanggupan dan kemampuan masing-masing itu menjadi satu kewajiban yang mutlak bagi setiap orang Islam tanpa kecuali selama hidupnya. Dakwah dapat dilakukan dengan bebagai cara. Ceramah adalah metode dakwah yang banyak digunakan oleh para ulama dalam menyampaikan ajaran-ajaran Islam kepada umat-Nya. Metode ini lebih banyak digunakan karena sangat mudah dan praktis untuk dilaksanakan. 
INTIQAD: JURNAL AGAMA DAN PENDIDIKAN ISLAM

ISSN 1979-9950 (print) || ISSN 2598-0033 (online), http://jurnal.umsu.ac.id/index.php/intiqad DOI: https://doi.org/10.30596/intiqad.v11i1.3138

Vol. 11, No. 1 (Juni 2019)

Dakwah pada dasarnya penyampaian ajaran Islam kepada manusia baik secara lisan maupun dalam bentuk sikap dan perilaku, diarahkan supaya timbul kesadaran dan mengamalkan setiap esensi ajaran Islam. Melihat dari perkembangannya, Pondok Pesantren sangat menekankan pentingnya mempelajari ilmu keIslaman dari pada ilmu-ilmu umum. Karena pesantren bertujuan meninggikan moral, melatih dan mempertinggi semangat, menghargai nilai-nilai spiritual dan kemanusiaan, mengajarkan sikap dan tingkah laku yang jujur dan bermoral, dan menyiapkan para murid untuk hidup sederhana dan bersih hati. Dari keterangan tersebut dapat disimpulkan bahwa aspek perilaku dan spiritualitas mendapat tekanan penting sementara ilmu-ilmu pemgetahuan umum yang lebih bersifat duniawi tidak disebutkan sama sekali. Secara lebih luas, Pondok Pesantren memiliki peranan sebagai tempat reproduksi ulama, tempat penyebaran dan pembejalaran ilmu-ilmu ke-Islaman, dan penjaga serta pemelihara tradisi Islam.

Pesantren merupakan lembaga pendidikan keagamaan yang mempunyai kekhasan tersendiri dan berbeda dengan lembaga pendidikan lainnya. Pendidikan di pesantren meliputi pendidikan Islam, dakwah, pengembangan kemasyarakatan dan pendidikan lainnya yang sejenis. Para peserta didik pada pesantren disebut santri yang umumnya menetap di pesantren. Tempat dimana para santri menetap, di lingkungan pesantren, disebut dengan istilah pondok. Dari sinilah timbul istilah pondok pesantren.

Pada tengah dinamika sistem kehidupan dunia yang mulai meninggalkan nilai-nilai moral dan pranata sosial, tampak jelas geliat lembaga-lembaga pendidikan Islam khususnya pesantren menyiapkan peserta didiknya menjadi manusia yang tidak saja memiliki kompetensi keilmuan dan life skill yang memadahi, namun juga menjunjung tinggi aspek moral sebagai landasan berpijak. Pesantren adalah tempat dimana calon-calon pengemban amanah negara tumbuh dan belajar membekali diri dengan menyeimbangkan kebutuhan material dan spiritual untuk menyongsong hirukpikuk masa depan. Kekuatan elit pesantren tidak diragukan lagi sebagai bagian integral dari kelompok agent of change diharapkan mampu memberikan kontribusi bagi pencerahan masyarakat. 
Pertumbuhan dan perkembangan pondok pesantren yang sangat pesat membuat lembaga pendidikan agama non-formal ini mengalami kenaikan jumlah yang signifikan dari masa ke masa, dengan kapasitasnya yang menyuguhkan spesialisasi kajian baik tradisional ataupun modern, maka pondok pesantren membawa dampak positif bagi perkembangan ilmu pengetahuan di negara ini. Jadi kehadiran pondok pesantren secara jelas dan nyata telah membantu pemerintah dalam rangka mencerdaskan kehidupan bangsa. Pondok pesantren menyimpan kekuatan yang sangat luar biasa untuk menciptakan keseluruhan aspek lingkungan hidup dan dapat memberi informasi yang berharga dan urgen dalam mempersiapkan kebutuhan yang inti untuk mencapai masa depan, kenyataan ini bahwa pondok pesantren hingga kini masih berperan penting dalam tiga hal, yaitu :

a) Pondok Pesantren sebagai lembaga pendidikan pengkaderan ulama, fungsi ini tetap melekat pada pondok pesantren, karna ia adalah satu-satu lembaga pendidikan yang melahirkan ulama. Namun walau demikian tuntutan modernisasi dan globalisasi mengharuskan ulama memiliki kemampuan lebih, kapasitas intlektual yang mamadai, wawasan, akses pengetahuan dan informasi yang cukup serta responsif terhadap perkembangan dan perubahan. b) Pondok Pesantren sebagai lembaga pengembangan ilmu dan pengetahuan khususnya agama Islam, dan pada tataran ini pondok pesantren memiliki peranan yang sangat besar dalam menyebarluaskan ilmu pengetahuan agama yang dalam pendidikan formal sering terabaikan. c) Pondok Pesantren sebagai transformator, motivator dan inovator. Kehadiran pondok pesantren dewasa ini telah memainkan perannya sebagai fungsi itu, meskipun dalam tataran tertentu masih perlu di kembangkan lebih lanjut, sebagai salah satu subsistem sosial pondok pesantren memiliki kekuatan dan daya tawar untuk melakukan perubahanperubahan yang berarti.

Sebagai kajian analisis peranan pondok pesantren dalam membangun dunia pendidikan, bahwa pondok pesantren memiliki kontribusi besar dalam membangun ilmu pengetahuan agama, karakter dan keperibadian santrisantrinya sebagai anakanak bangsa, kemudian peranan ini berdampak positif 
terhadap pertumbuhan dan perkembangan pondok pesantren di Indonesia yang notebene didirikan oleh santrisantri cerdas selepas mereka menyelesaikan pendidikannya di pondok pesantren, seiring dengan pertumbuhan dan perkembangan itu, jumlah madrasah juga ikut meningkat lantaran pondok pesantren yang didirikan biasanya memiliki madrasah sebagai alternatif pendidikan formal, Oleh karna itu, perkembangan pondok pesantren selama ini diyakini sebagai salah satu faktor penting dalam membantu pertumbuhan madrasah di tanah air.

\section{Metode Penelitian}

Lokasi penelitian dilakukan di pondok pesantren Az-Zuhroh Besilam yang beralamatkan di Desa Besilam Kecamatan Padang Tualang Kabupaten Langkat.

Subjek penelitian merupakan sumber data yang dimintai informasinya sesuai dengan masalah penelitian. Adapun yang dimaksud sumber data dalam penelitian adalah subjek dari mana data diperoleh. ${ }^{9}$ Dari subjek

\footnotetext{
${ }^{9}$ Suharsimi Arikunto, Prosedur Penelitian Suatu Pendekatan Praktek. Cetakan
} ke 15. (Jakarta: PT Rineka Cipta, 2013), h. 172. penelitian inilah data informasi di dapat secara akurat baik dari orang maupun dari sesuatu sehingga data yang diperoleh dapat digunakan dalam penelitian tersebut. Dalam penelitian ini, karakteristik subjek penelitian ini adalah kepala pondok pesantren, para dewan guru, dan para santri pondok pesantren Az-Zuhroh.

Permasalahan yang akan dikaji oleh peneliti merupakan masalah yang bersifat sosial dan dinamis. Oleh karena itu, peneliti memilih menggunakan metode penelitian kualitatif untuk menentukan cara mencari, mengumpulkan, mengolah dan menganalisis data hasil penelitian tersebut. Penelitian kualitatif ini dapat digunakan untuk memahami interaksi sosial, misalnya dengan wawancara mendalam sehingga akan ditemukan pola-pola yang jelas.

Penelitian kualitatif yaitu metode penelitian yang berlandaskan pada filsafat postpositivisme, digunakan untuk meneliti pada kondisi objek yang alamiah, (sebagai lawannya adalah eksperimen), sumber data dilakukan secara purposive dan snowbaal, teknik pengumpulan dengan trianggulasi (gabungan), analisis data bersifat 
Vol. 11, No. 1 (Juni 2019)

induktif/ kualitatif, dan hasil penelitian kualitatif lebih menekankan makna dari pada generalisasi."

Secara teoritis format penelitian kualitatif berbeda dengan format penelitian kuantitatif. Perbedaan tersebut terletak pada kesulitan dalam membuat desain penelitian kualitatif, karena pada umumnya penelitian kualitatif yang tidak berpola. Dalam penelitian ini digunakan metode kualitatif dengan desain deskriptif, yaitu penelitian yang memberi gambaran secara cermat mengenai individu atau kelompok tertentu tentang keadaan dan gejala yang terjadi.

Pendekatan yang digunakan dalam penelitian ini adalah pendekatan Kualitatif yang berkarakter deskritif. Pendekatan kualitatif yang berkarakter deskritif dalam penelitian ini dilakukan dengan alasan bahwa dalam kegiatan ini peneliti tidak menggunakan angka dalam mengumpulkan data dan dalam memberikan penafsiran terhadap hasilnya. Pendekatan ini dilakukan karena data yang terkumpul analisisnya lebih bersifat kualitatif. Karekter deskriptif terlihat pada penggambaran

\footnotetext{
${ }^{10}$ Sugiyono, Metode Penelitian Pendidikan Pendekatan Kuantitatif, Kualitatif dan R dan D. (Bandung : Alfabeta, 2008), h.15.
}

tentang kontribusi Pondok Pesantren AzZuhroh Besilam dalam melahirkan mubaligh di Kabupaten Langkat

\section{Hasil Penelitian dan Pembahasan}

Pondok Pesantren (Pontren) merupakan lembaga pendidikan Islam tertua di Indonesia yang tumbuh bersamaan dengan masa penyiaran Agama Islam.Pontren pada umumnya didirikan oleh ulama/kyai dengan kemandirian, kesederhanaan dan keikhlasan.Pada masa pra kemerdekaan Pontren telah berperan besar dalam melahirkan pejuang-pejuang yang tangguh dalam memperjuangkan kemerdekaan.Setelah kemerdekaan Pontren terus berperan dalam mencerdaskan kehidupan bangsa (Tafaqquh fi al-din) dan memberikan pelayanan sosial (dakwah bil hal) dalam menyiapkan tenaga-tenaga yang menguasai ilmu-ilmu keislaman sebagai kader ulama, muballigh atau Guru Agama yang sangat dibutuhkan oleh masyarakat. Hingga kini lembaga tersebut tetap konsisten terhadap peranannya, kendatipun oleh sebagian masyarakat dipandang sebagai pendidikan alternatif dan merupakan 
Vol. 11, No. 1 (Juni 2019)

lembaga pendidikan kelas dua dalam sistem pendidikan nasional.

Seiring dengan perkembangan zaman, pendidikan di Pontren pun banyak mengalami perubahan khususnya dalam penyelenggaraan pendidikan. Sebagian Pontren menggunakan sistem madrasah/klasikal dan kurikulumnya menyesuaikan dengan kurikulum Pemerintah dengan menyelenggarakan MI, MTs, MA atau menyelenggarakan SD, SMP dan SMA/SMK bahkan sampai Perguruan Tinggi, namun sebagian pesantren masih tetap mempertahankan sistem pendidikan khas pesantren secara mandiri baik kurikulumnya maupun proses pembelajaran dan pendidikannya. Bahan ajar di pesantren meliputi ilmu-ilmu Agama Islam dengan menggunakan kitab-kitab berbahasa Arab sesuai dengan tingkatannya masing-masing. Pembelajaran dengan cara sorogan, wetonan dan bandongan masih tetap dipertahankan, tetapi sudah banyak juga yang telah menggunakan klasikal dalam bentuk Madrasah seperti Madrasah Diniyah Tingkat Ula/Awaliyah, Tingkat Diniyah Wustho dan Tingkat Diniyah Ulya. Sebagian lagi menggunakan model Kuliyatul Mu'allimin Al-Islamiyah
(KMI), Dirasatul Mu'allimin AlIslamiyyah (DMI) dan Tarbiyatul Mu'allimin Al-Islamiyah (TMI).

Disadari bahwa selama ini perhatian dan pengakuan (recognition) pemerintah terhadap institusi pesantren khususnya yang tidak menyelenggarakan pendidikan Madrasah/Sekolah formal masih sangat minim, bahkan tamatan Persantren belum mendapat pengakuan mu'adalah/kesetaraan, sehingga sering menemui kesulitan untuk melanjutkan belajar ke jenjang pendidikan yang lebih tinggi maupun untuk melamar pekerjaan pada sektor formal. Padahal selama ini, masyarakat telah memberikan pengakuan terhadap kualitas lulusan Pesantren, dan bahkan sebagian dari lembaga pendidikan di luar negeri pun telah memberikan pengakuan kesetaraan (mu'adalah) terhadap pendidikan di pondok pesantren. Oleh karena itu, berdasarkan pada Undang-Undang Sisdiknas nomor 20 tahun 2003 pasal 30 ayat 3,dan 4 serta PP tentang Standar Nasional Pendidikan (SNP) nomor 19 tahun 2005 pasal 93, maka pendidikan di pondok pesantren sudah mendapatkan pengakuan yang jelas, dan memperoleh fasilitas yang sama seperti institusiinstitusi pendidikan lainnya manakala 
mengikuti regulasi-regulasi yang telah ditetapkan pemerintah dalam dunia pendidikan.

Hal yang penting untuk diingat adalah bahwa pondok pesantren memiliki program pendidikan yang disusun sendiri (mandiri) di mana program ini mengandung proses pendidikan formal, non formal maupun informal yang berlangsung sepanjang hari dalam satu pengkondisian di asrama. Sehingga dari sini dapat dipahami bahwa pondok pesantren secara institusi atau kelembagaan dikembangkan untuk mengefektifkan dampaknya, pondok pesantren bukan saja sebagai tempat belajar melainkan merupakan proses hidup itu sendiri, pembentukan watak dan pengembangan sumber daya.

Perubahan dan perkembangan sistem pendidikan pondok pesantren dipengaruhi beberapa faktor selain tuntutan zaman, seperti; tuntutan kesiapan pondok pesantren mengimbangi lembaga pendidikan lain yang dianggap siap pakai. Di samping itu ada hal lain yang menyebabkan sistem pondok pesantren mengalami pergeseran, seperti; modernisasi sistem pendidikan, faktor penjajahan dan sebagainya. Kendatipun terdapat pergeseran dan perubahan, sistem yang dikembangkan pondok pesantren, subtansinya tidak mengalami perubahan.Pondok pesantren sebagai lembaga pendidikan keagamaan masih tetap dipertahankan, sementara beberapa pondok pesantren berjalan dengan segala tradisi yang mewarisinya, secara turun temurun tanpa variasi.

Sebagai institusi pendidikan, pondok pesantren di Indonesia harus memiliki landasan yang jelas secara yuridis.Hal ini memiliki implikasi terhadap akreditas sebuah lembaga tersebut, akreditasi tersebut terkait dengan pengakuan alumni pondok pesantren itu sendiri.Pada awal-awal tumbuh dan berkembangnya pondok pesantren, akreditas sudah cukup bila kyai memberikan "ijazah" terhadap santri. Tuntutan zaman menghendaki perubahan dan akreditas dalam bentuk lain, oleh sebab itu pondok pesantren harus mempunyai legalitas. Dengan memiliki legalitas tersebut maka santri yang tamat dari pondok pesatren diakui dan disamakan administrasi dengan sekolah pada umumnya

Keberadaan sebuah institusi di Indonesia harus memiliki dasar hukum 
yang jelas, dan tidak keluar dari perundang-undangan yang berlaku. Seperti institusi lain, pondok pesantren (lembaga pendidikan) memiliki landasan yuridis formal yaitu Undang-Undang Republik Indonesia Nomor 20 Tahun 2003, khususnya bab II pasal 2 dan 3 sebagai berikut:

"Pendidikan Nasional berdasarkan pancasila dan Undang-Undang Dasar Negara Republik Indonesia Tahun 1945", "Pendidikan Nasional berfungsi mengembangkan kemampuan dan membentuk watak serta peradaban bangsa yang bermartabat dalam rangka mencerdaskan kehidupan bangsa, bertujuan untuk berkembangnya potensi peserta didik agar menjadi manusia yang beriman dan bertakwa kepada Tuhan Yang Maha Esa, berakhlak mulia, sehat, berilmu, cakap, kreatif, mandiri dan menjadi warga negara yang demokratis serta bertanggung jawab". ${ }^{11}$

Landasan yang disebutkan di atas memuat prinsip-prinsip umum pendidikan dan hak setiap warga negara dalam memperoleh dan memajukan pendidikan.Memperoleh pendidikan bisa

${ }^{11}$ Undang-undang Republik Indonesia Nomor 20 Tahun 2003 Tentang Sistem Pendidikan Nasional (Sisdiknas), (Bandung: Fokus Media, 2005), h. 4. didapati melalui lembaga pendidikan yang disediakan oleh pemerintah dan swasta.Sedangkan memajukan pendidikan dapat diwujudkan dalam bentuk menyediakan institusi pendidikan yang dikelola oleh pihak swasta.

Pondok pesantren adalah suatu lembaga pendidikan swasta yang didirikan oleh perseorangan (kyai) sebagai figur central yang berdaulat menetapkan tujuan pendidikan pondoknya adalah mempunyai tujuan tidak tertulis yang berbeda-beda. Sikap filosofis para kyai secara individual tidak sama, ada yang luas ada yang sempit. Tujuan tersebut dapat diasumsikan sebagai berikut:

1. Tujuan khusus: "mempersiapkan para santri untuk menjadi orang yang alim dalam ilmu agama yang diajarkan oleh kyai yang bersangkutan serta mengamalkannya dalam masyarakat".

2. Tujuan umum: "membimbing anak didik untuk menjadi manusia yang berkepribadian Islam yang sanggup dengan ilmu agamanya menjadi 
mubaligh Islam dalam masyarakat melalui ilmu dan amalnya". ${ }^{2}$

Tujuan pondok pesantren yaitu membentuk mubalig-mubalig Indonesia berjiwa Islam yang pancasialis yang bertakwa, yang mampu baik rohaniah maupun jasmaniah mengamalkan ajaran agama Islam bagi kepentingan kebahagiaan hidup diri sendiri, keluarga, masyarakat dan bangsa, serta negara Indonesia. Pendidikan dan pembinaan pada setiap pondok pesantren memiliki tujuan sendiri-sendiri yang menjadi ciri khasnya.Namun menurut Nurcholish Madjid, ketidaktegasan pondok pesantren dalam merumuskan tujuan dan langkah pembinaan yang menjadikan pesantren sering tertinggal bila dibandingkan dengan pendidikan umum.Faktor yang dianggap mempengaruhi kaburnya tujuan pendidikan pondok pesantren sering dipengaruhi semangat pendiri pondok pesantren.

Tujuan pembinaan santri pada pondok pesantren adalah membentuk manusia yang memiliki kesadaran tinggi bahwa ajaran Islam merupakan nilai-nlai

12 M. Arifin, Kafita Selekta Pendidikan islam (Islam dan Umum). (Jakarta, Bumi Aksara, 2000), h. 248 yang bersifat menyeluruh. Selain itu produk pesantren diharapkan memiliki kemampuan tinggi untuk mengadakan respons terhadap tantangan-tantangan dan tuntutan-tuntutan hidup dalam konteks ruang dan waktu.Semua pondok pesantren telah mampu menjadikan manusia memiliki kesadaran Islam adalah nilai yang mencakup seluruh kehidupan.Tetapi bila dilihat dari kesiapan pondok pesantren dalam melakukan pembinaan dan pendidikan untuk menjawab tantangan zaman, tidak seluruh pondok pesantren mampu.Hal ini disebabkan oleh orientasi dan motivasi pondok pesantren tersebut. Oleh sebab itu perumusan kembali metode pembinaan dan pendidikan santri pada pondok pesantren sehingga memiliki kesiapan dalam menjawab tantangan zaman.Pembinaan dan pendidikan menjadi bagian terpenting dalam mewujudkan keberhasilan, sehingga perlu penyisipan aspek umum yang dianggap penting.Dengan demikian, pendidikan dan pembinaan santri pada pondok pesantren lebih bersifat holistik.

Sebagai basis pendidikan Islam, pondok pesantren memang bisa dikatakan sebagai tempat strategis dalam melahirkan ulama-ulama, Kiyai, bahkan 
Vol. 11, No. 1 (Juni 2019)

tokoh-tokoh besar yang memiliki pemahaman tinggi terhadap agama Islam.Disamping itu, pondok pesantren juga lebih menarik minat khususnya orang-orang desa karena biayanya yang lebih murah daripada sekolah formal.Namun dalam perkembangannya, Pondok Pesantren kini bukan hanya diminati masyarakat desa, namun keberbagai lapisan masyarakat karena terobosan-terobosan yang ada di Pondok Pesantren tersebut.

Jika masa dulu pondok pesantren identik dengan pendidikan bagi generasi muda pedesaan dan pinggiran kota, namun pondok pesantren sekarang pemuda kota pun bisa belajar di Pesantren. Selain itu, Pondok Pesantren sekarang juga sudah mengalami kemajuan yang pesat, terbukti dengan banyaknya pondok pesantren yang berlabelkan Pondok Pesantren Modern.Sehingga lembaga ini berhasil menarik minat berbagai lapisan masyarakat yang semakin banyak dan otomatis Pondok Pesantren sekarang semakin besar peranannya dalam mengembangkan Pendidikan Agama Islam.

Pesantren merupakan lembaga pendidikan tradisional Islam untuk memahami, menghayati dan mengamalkan ajaran Islam dengan menekankan pentingnya moral agama Islam sebagai pedoman hidup bermasyarakat sehari-hari.Pesantren sendiri menurut pengertian dasarnya adalah tempat belajar para santri.Sedangkan pondok berarti rumah atau tempat tinggal sederhana yang terbuat dari bambu.Disamping itu kata "pondok" mungkin juga berasal dari bahasa Arab "funduq" yang berarti hotel atau asrama.

Pondok pesantren yang merupakan "bapak" dari pendidikan Islam di Indonesia, didirikan karena adanya tuntutan dan kebutuhan zaman, hal ini bisa dilihat dari perjalanan historisnya, bahwa sesungguhnya pesantren dilahirkan atas kesadaran kewajiban dakwah-dakwah Islamiah, yakni menyebarkan dan mengembangkan ajaran Islam, sekaligus mencetak kaderkader ulama dan da'i.

Mengajak manusia menuju agama Allah merupakan salah satu ibadah yang agung, manfaatnya menyangkut orang lain. Bahkan dakwah menuju agama Allah merupakan perkataan yang paling baik. Allah Swt berfirman dalam surah Fushshilat ayat 33 sebagi berikut: 


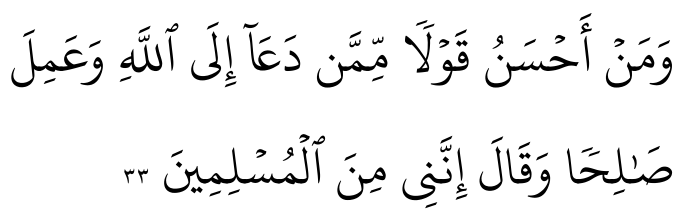

Artinya: Siapakah yang lebih baik perkataannya daripada orang yangmenyeru kepada Allah, mengerjakan amal yang saleh, dan berkata: "Sesungguhnya Aku termasuk orang-orang yang menyerah diri?" (QS. Fushshilat: 33$)^{13}$

Dakwah mengajak kepada agama Allah merupakan tugas para nabi, maka cukuplah sebagai kemuliaan bahwa para da'i mengemban tugas para nabi. Allah Swt memerintahkan Rasul-Nya untuk mengatakan dan mengabarkan kepada orang lain, dakwah merupakan jalan Beliau, dengan firman-Nya dalam surah Yusuf ayat 108:

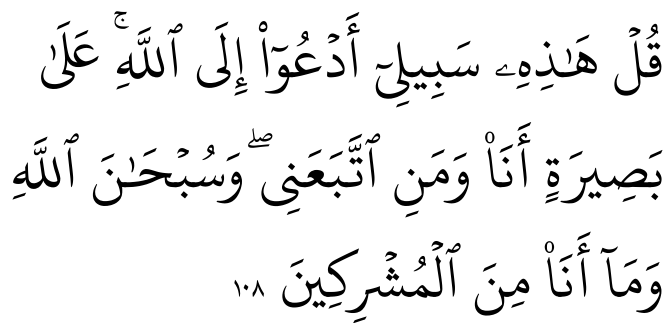

Artinya: Katakanlah: "Inilah jalan (agama) ku, Aku dan orang-orang yang mengikutiku mengajak (kamu) kepada Allah dengan hujjah yang nyata, Maha Suci Allah, dan Aku tiada termasuk

\footnotetext{
${ }^{13}$ Departemen Agama RI, Al-Qur'an Tafsir Perkata Tajwid Kode Angka. Tangerang : Kalim, 2012), h. 457.
}

orang-orang yang musyrik". (QS. Yusuf: $108)^{14}$

Karena dakwah merupakan ibadah, maka harus dilakukan dengan keikhlasan dan mengikuti Sunnah Nabi Muhammad SAW. Sebagaimana telah maklum, dua perkara ini merupakan syarat diterimanya ibadah.Dengan dakwah manusia dapat memahami Islam dengan baik dan benar sehingga menjalankan ibadah sesuai dengan tuntutan ajaran agama Islam.Karena dakwah terdapat ajaran-ajaran agama yang di sampaikan pendakwah.

Dampak pondok pesantren tidak hanya sebagai simbol lembaga keagamaan, tetapi dampaknya lebih besar daripada itu.Pondok pesantren sangat berpengaruh terhadap pergerakan pendidikan, dakwah, politik dan sosial masyarakat.Di samping itu pondok pesantren melahirkan ulama-ulama baru yang dahulunya adalah santri.Peran ulama dan santri juga hadir di tengahtengah masyarakat sebagai juru cakap yang mampu menyelesaikan persoalan umat sehingga menjadi agen pergerakan.Dengan adanya pendakwa

\footnotetext{
${ }^{14}$ Departemen Agama RI, ...., h. 236.
} 
manusia akan lebih mudah memahami ajaran agama dengan baik dan benar.

Salah satu tujuan yang terpenting dari syari'at Islam adalah menyemaikan bibit kebaikan.Tujuan utama dari pola ini adalah untuk membangun kehidupan manusia di atas makrufat (kebaikankebaikan) dan membersihkannya dari hal-hal yang mungkarat (kejahatankejahatan).Dakwah mengajak manusia kepada Allah Swt, sedangkan mendidik adalah membina dan mengajarkan manusia.Sehingga dakwah dan mendidik tidak dapat dipisahkan, di dalam dakwah ada nilai pendidikan sedangkan mendidik ada nilai dakwah.

Dakwah dan mendidik merupakan tugas semua Nabi dan Rasul yang pernah diutus oleh Allah Swt di permukaan bumi ini yang dimulai dari Nabi Adam as.sampai kepada Nabi Muhammad saw sebagai penutup dari semua Nabi. Olehnya itu untuk menyampaikan dan mendakwakan kepada setiap orang yang mengaku sebagai pengikut Nabi Muhammad Saw. Hal ini sebagaimana firman Allah SWT disebutkan dalam surah Saba' ayat 28 sebagai berikut :

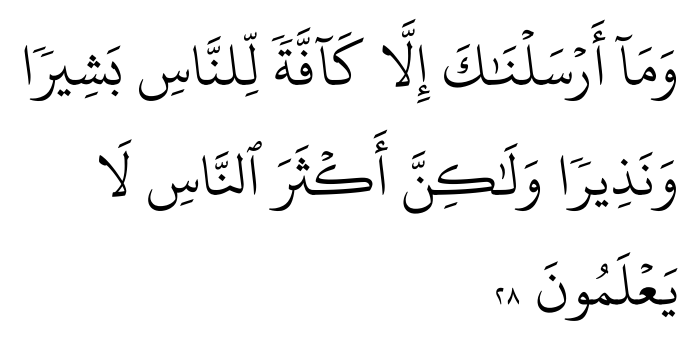

Artinya: Dan kami tidak mengutus kamu, melainkan kepada umatmanusia seluruhnya sebagai pembawa berita gembira dan sebagai pemberi peringatan, tetapi kebanyakan manusia tiada Mengetahui. (QS. Saba': 28) ${ }^{15}$

Untuk mendapatkan kader yang militan dan tangguh dalam berdakwah ke pelosok nusantara.Maka peran pesantren sangat di butuhkan dalam pembinaan para mubaligh dalam menyampaikan ajaran agama Islam kepada masyarakat-masyarakat yang belum memahami Islam dengan baik.Oleh Karena itu pondok pesantren AzZuhrah Besilam Babussalam melakukan terobosan dalam melahirkan kader pendakwah.

\section{E. Simpulan}

1. Pondok Pesantren pondok pesantren Az-Zuhrah Besilam Babussalam berdiri dibawah naungan Yayasan Az-Zuhroh Besilam 2002 yang didirikan oleh Alm. H. Madyan A. Jalil. Nomor Induk Statistik: 510312050014 dan

\footnotetext{
${ }^{15}$ Departemen Agama RI, ...., h.
} 
INTIQAD: JURNAL AGAMA DAN PENDIDIKAN ISLAM

ISSN 1979-9950 (print) || ISSN 2598-0033 (online), http://jurnal.umsu.ac.id/index.php/intiqad DOI: https://doi.org/10.30596/intiqad.v11i1.3138

Vol. 11, No. 1 (Juni 2019)

Nomor Izin: Kd.02.02/6/ PP.007/

SK/ 1674/ 2010 pada tanggal 10 Desember 2010. Pondok pesantren Az-Zuhrah mengalami pertumbuhan dan perkembangan yang bagus dari awal berdirinya hingga saat ini. Hal ini ditandai dengan jumlah santri tiap tahunnya semakin banyak, santri/santriwati mewakili berbagai lomba di MTQ baik tingkat kecamatan maupun tingkat Kabupaten serta menciptakan hafizhafizah qur'an (penghafal Alqur'an) dan para mubaligh muda.

2. Sistem pembinaan di Pondok Pesantren Az-Zuhrah Besilam Babussalam terkait dalam pengembangan bakat dan minat siswa dibuat dalam bentuk kegiatan ekstrakurikuler seperti kader dakwah.

3. Peran serta kontribusi yang diberikan oleh Pondok Pesantren Az-Zuhrah Besilam Babussalam dalam melahirkan para mubaligh muda yang handal dengan mendukung berbagai program yang ada sehingga santri dapat mengembang potensi berdakwahnya.
4. Lembaga pendidikan Islam yang dikembangkan melalui pondok pesantren Az-Zuhrah Besilam Babussalam merupakan peengembangan misi dakwah dan pendidikan kepada masyarakat khususnya perlu secara terus menerus dikembengkan secara internal denagan tetap meningkat sarana prasarana pendukung, tenaga pengajar, dan kegiatan pesantren yang lebih inovatif dalam proses pembalajaran.

\section{Daftar Pustaka}

Al-Qur'anul Karim

Arikunto, S. (2013). Prosedur Penelitian Suatu Pendekatan Praktek. Cetakan ke 15. Jakarta: PT Rineka Cipta.

Arifin, H. M. (2000a). Psikologi Dakwah. Jakarta: PT Bumi Aksara. Arifin, H. M. (2000b). Kafita Selekta Pendidikan islam (Islam dan Umum). Jakarta, Bumi Aksara.

Departemen Agama RI Dirjen Kelembagaan Agama Islam. (2004). Keterpaduan Materi PAI dengan Ilmu Pengetahuan dan Teknologi. 


\section{INTIQAD: JURNAL AGAMA DAN PENDIDIKAN ISLAM}

ISSN 1979-9950 (print) || ISSN 2598-0033 (online), http://jurnal.umsu.ac.id/index.php/intiqad DOI: https://doi.org/10.30596/intiqad.v11i1.3138

Vol. 11, No. 1 (Juni 2019)

Departemen Agama RI. (2005). AlQur'an Tafsir Perkata Tajwid Kode Angka. Tangerang : Kalim.

Fauzi, M. H. Santri pondok pesantren Az-Zuhrah Besilam Babussalam. Wawancara tanggal 9 Januari 2018.

Hamdani. (2011). Strategi Belajar Mengajar. Bandung: Pustaka Setia.

Majid, A dan Andayani, D. (2005). Pendidikan Agama Islam Berbasis Kompetensi, Bandung: PT. Remaja Rosda Karya.

Nakhrawie, A. An. (2013). Islam Itu Mudah Mengapa Dipersuli. Lamongan : Lumbung Insani.

Ramayulis dan Nizar, S. (2010). Filsafat Pendidikan Islam. Cetakan ke 2. Jakarta: Kalam Mulia.

Ramayulis. (2002). Ilmu Pendidikan

Islam. Cetakan 3. Jakarta: Kalam Mulia.

Sadiman, Arief S, dkk. (2008). Media Pendidikan: Pengertian,

Pengembangan dan

Pemanfaatannya. Jakarta : PT. Raja Grafindo Persada.

Sharif, al-Qarashi Baqir. (2003). Seni Mendidik Islami. Terjemahan
Mustafa Budi Santoso. Jakarta : Pustaka Zahra.

Sofyan, M. (2009). Serba-serbi Hidup Qur'ani. Medan : Duta Azhar.

Solatun. (2007). Islam dan Etika Komunikasi. Jakarta : Image.

Sudijono, A. (2009). Pengantar Evaluasi Pendidikan. Cetakan 3. Jakarta: PT. Raja Grafindo Persada.

Sugiyono. (2008). Metode Penelitian Pendidikan Pendekatan

Kuantitatif, Kualitatif dan $R$ dan D. Bandung : Alfabeta.

Sutrisno. (2011). Pembaharuan dan Pengembangan Pendidikan Islam. Yogyakarta : Fadilatama.

Tohirin. (2008). Psikologi Pembelajaan Pendidikan Agama Islam. Jakarta : PT. Raja Grafindo Persada.

Undang-Undang Republik Indonesia Nomor 20 Tahun 2003 Tentang Sistem Pendidikan Nasional (Sisdiknas). (2005) .Bandung : Fokus Media.

Putra, H. (2009). Sejarah Pertumbuhan dan Pembaruan Pendidikan Islam di Indonesia. Jakarta: Kencana.

Whitehead, A.N. (2009). Mencari Tuhan Sepanjang Zaman. Penerjemah Alois Agus Nugroho. Bandung : Mizan. 
INTIQAD: JURNAL AGAMA DAN PENDIDIKAN ISLAM

ISSN 1979-9950 (print) || ISSN 2598-0033 (online), http://jurnal.umsu.ac.id/index.php/intiqad DOI: https://doi.org/10.30596/intiqad.v11i1.3138

Vol. 11, No. 1 (Juni 2019)

Zeeno, S.M. B. J. (2000). Bimbingan

Islam Untuk Pribadi dan

Masyarakat. Jakarta: Darul Haq. 